\title{
Challenges that Confront the Human Development in Jordan and Means of Limiting Them
}

\author{
Hamzeh Ismail Ibrahim Abu Shari'ah ${ }^{1}$ \\ 1 The World Islamic Sciences \& Education University (WISE), Amman, Jordan \\ Correspondence: Hamzeh Ismail Ibrahim Abu Shari'ah, The World Islamic Sciences \& Education University \\ (WISE), Amman, Jordan
}

Received: January 2, 2020

Accepted: January 23, 2020

Online Published: January 27, 2020

doi:10.5539/mas.v14n2p36

URL: https://doi.org/10.5539/mas.v14n2p36

\begin{abstract}
The study aims at recognizing the human development as a worldly phenomenon and its challenges on the human development, especially in Jordan, being the most important and powerful resources to confront the challenges, meanwhile the study problematic had circulated in an axial question meaning what are the challenges that confront the human development and how to surmount them, and make barrier against achieving objectives of the state through the qualified human resources, reaching the welfare of the community and make happy its individuals? To answer the question of study and achieve its objectives. The study had employed the analytical descriptive method, and the study came asserting the correctness of this hypothesis. The study had made us deduce many deductions the most important of them is that the human development concentrates on achieving the economic development, not only to pure economic objectives, but another political, social, and environmental and at a truthful link with objectives of security and settlement. And the study obliged many deductions, the most important of which is laying a comprehensive strategy for the economic, social, and political development in Jordan.
\end{abstract}

Keywords: challenges, development, human development

\section{Introduction}

The human development occupies an entrance or a method aims at correcting the economic, financial, and monetary policies, and in a more correct meaning, it is a tool of reformation process in the economic defect that took place in the economies of the world because of slowness in averages of economic growth, aggravation of inflation averages, and increase of indebtedness. The thing that led to severe results, and ascending social and economic problems, such as unemployment and enlarging the gap between the rich and the poor people and weakness of belongingness to the acting political system and abstention from participation in the political process. These data all led to losses in development returns, and weakness of the economic performance averages, the thing that was negatively reflected on human beings and their human security.

It should not be absented from the mind that the best usage of the human development depends on the size of the acting powers, which in turn leans the size of population, averages of their development and the prevailing customs in the community, and also lean on skills of workers and the extent of availability of the qualified powers to achieve their objectives.

\subsection{Significance of Study}

Significance of study springs from being the Jordanian community confronts a group of great challenges, because of the consecutive swift changes at all sides and domains that make a barrier between the human resources and their development where the human element forms the highest significance in the comprehensive power of the state and is considered the basis of every advancement, the more challenges and risks subdued that hinder the work the matter led to improvement of life type in the community, and the significance springs from being the Jordan community is like the other communities exposed to more of challenges that threaten to catch the sharpest hurts headed by degrading the human development...so it becomes confined to producing the lowest limit required.

But the practical significance springs from the decision-makers' advancement in the domain of human development to avoid the challenges that confront the human resources during the stages of preparing the public 
policy of the establishment to which they belong, and so about preparing the established programs, and assisting in laying the contradictive plans guaranteed by confronting the present and possible challenges.

\subsection{Motives of Study Choice}

After clearing the significance of study and before discussing its problem and objectives we have to illustrate our choice of the subject: "Challenges that confront the human development in Jordan and means of limiting them", they were not spontaneous, but basically refer to the states particular interests in the human resources from part of subduing the challenges they confront, and they are in the verdict of handicaps that hinder escorting hastening developments in the domain of productivity entrusted by it, not at this limit, but to the shaking of productivity too if treatment of challenges had not been done by a serious scientific treatment, the choice of the subject can be caused by the following:

a. Significance of the human resources and styles of developing them lead to activating energies, and reaching goals entrusted by them, and they are numerous with branching phases, and this is not done, except by overstepping challenges and their submission.

b. Control of financial resources and directing them the correct direction towards developing the human resources, that is for extinguishing corruption, and exploiting the human development as a type of wasting public money, that forms a primary challenge in the subject of human development.

c. Diagnosing the challenges that share, in turn, in their role of directing efforts for treating them, and this leads to non-wasting time.

d. Challenges of human development are a reality should not be forgotten or ignored, and require review in many things that govern the process of human development in Jordan.

e. Perception of the problem as a self-motive to choose the study and then diagnose means of limiting its challenges.

\subsection{Problem of Study}

It is evident through motives of choosing the subject and significance of study, the problem of study conceals in the extent of ability to surmount challenges that are considered risks and difficulties object means of human development until they perform the role required from them, for this we may formulate the problem by an axial question enquiring: what are the challenges that confront the human development and how to surmount them and make a barrier against achieving objectives of the state through the qualified human resources attaining the welfare of the community and making happy its individuals?

And branches from this question many subsidiary questions, they are:

a. What are the challenges belonged to the economic field in Jordan.

b. What are the challenges belonged to the political field in Jordan.

c. What are the challenges belonged to the social field in Jordan.

d. What are the challenges belong to the environmental field in Jordan.

e. What are the means of limiting the development challenges in Jordan.

\subsection{Objectives of Study}

This study seeks achieving the following objectives:

a. Clearing the challenges belong to the economic side in Jordan.

b. Raising the challenges belong to the social side in Jordan.

c. Recognizing the challenges belong to the political side in Jordan.

d. Recognizing the challenges belong to the environmental side in Jordan.

e. Illustrating the means for the sake of limiting the development challenges in Jordan.

\subsection{Hypothesis of Study}

This study is performed on two basic hypotheses, they are:

a. That there is a connective relationship between the challenges and human development.

b. There is a shortage in the possibilities led to inflation of the human development in Jordan. 


\subsection{Previous Studies}

There are numerous previous studies tackled the subject of development, from them:

- Ahmad's study (2012) entitled "Developing the Human Resources from an Islamic Perspective", this study tackled developing the human resources from an Islamic perspective, where it was pin-pointed that the term "development" was not provided in the Holy Qura'n, but abundant concepts had been provided in it indicate to it, such as the earth reformation, for this concept is performed on the condition of caliphate on earth, in which the natural resources are exploited for the human being to work on producing goods and services to serve the implored human beings.

- Sauzan's study (2013), entitled "Human Development in Algeria: Reality and Horizons", the study aimed at shedding light on Algeria and following up the track of its development, getting acquainted with the human development in Algeria through indicators of human development.

- Activity study (2014), entitled "The social challenges and their effect on the Development of Human Resources: a Sociology Entrance". The study had aimed at pinpointing the size of variation existing between the nature of human possibilities balanced to attain an appropriate level at the outlets aiming at service, production and effectiveness.

- Zahow study (2015), entitled "The Human Development in Iraq in the shadow of knowledge economy, that is by depending on analyzing some indications of health, education and level of income and comparing it with identical for some Arab states that passed a long run in the domain of human development.

- Al-Seyabi study (2017) entitled "Human Development and Its Impact in the Omani Community to Achieve the Everlasting Development" tackled clearing the concepts, domains, objectives, challenges, and indicators of the human developments, especially indicators of the governmental expenditure in what concerns (health, education, and average of the individual's income) and their impact on the workers' community to achieve the everlasting development.

But this study is distinguished from others of previous studies by the following: this study is considered a study with specialization being tackled challenges of the human development in Jordan, in addition to that this study after it had diagnosed the challenges, it took with means of limiting and overstepping these challenges obtaining the effective human development.

\subsection{Terms of Study}

\subsubsection{Challenges}

There exists no definition agreed upon, fair to be comprehensive to the concept of challenges, that refer to the outlook of every researcher, therefore it is possible to provide some of them. Some people defined it: "That they are the difficulties and risks or the restrictions that threaten the ability of the organization and prevent them from achieving its objectives or ascending what it suffers from problems" (Fathi, 2005: 16). "It was defined that it is: a case or a non-appropriate circumstance, its survival forms a threat to any organization or association and forms a barrier against it, and achieves its objectives (Suleiman, 1436h.: 3).

Referring to what preceded ..challenges are nothing, but: (those difficulties that form a barrier against the human resources and achieving the objectives of the association or the organization in which it works) too.

\subsubsection{The Human Development}

There are plenty of definitions, came by people of specialization and interested people in human development, inspite of difference in definition, but they all fulfill one purpose and from these definitions, that it is "reaching with man to the acceptable limit to level of living, it is not obliged to give it up considering it a right for every citizen the state is committed to it and enhances the local efforts to achieve efficiency of using the available possibilities" (Mohammad, 1984: 20).

And it is known too that it is "Satisfaction of social needs of the human being by issuing legislations and laying the programs carried out by the public and private corporations" (Hasan, 1998: 91). Also it is defined that it is: "the process drawn to advancement of the community by all its economic, social, cultural and the political dimensions" (Al-Jawhari, 1986: 440).

And leaning on what preceded, development can be defined as: (A great flow of the societal procedures sought by governments to achieve the welfare of the human being and attain his objectives). 


\subsubsection{Human Resources}

Definitions of the human resources are abundant, from them what the lexicon of administrative terminology deals with, it provided: "human resources are all the human elements of managers and employees at their different levels who are performing an action in the establishment" (Al-Burai' 1993: 37). And another definition of the human resources of any state or organization came that they are: "those groups of wishing and able individuals to perform work at a good and commitment form, where it has to be integrated and ability to interact with wish in a harmonious frame to increase the opportunity of effective benefitting from these resources" (Al-Sadeq, 2012).

And they were defined too as: "the working group at any association or organization performed on work, planning, organization, directing and control at its extreme effort and thinking to achieve objectives of the association or the organization to it is belonging" (Radwan, 2013: 3).

Leaning on what preceded, human resources can be defined as: "The human element working at the governmental associations and organizations and nongovernmental ones committed with what the employing party of that element requires to achieve their objectives".

Therefore, the concept of human development is nothing but is the process that concentrates on man and seeks to develop his skills and abilities to obtain a good living level, considering human as the truthful wealth of nations, so it has to surmount challenges and obstacles in the face of human track...it is active in its seeking to achieve the economic, political, and social accomplishments aiming at making happy the human being.

\subsection{Methodology of Study}

Achieving objectives of study and answering its questions, this study was performed on two methodologies serving the practical trends, they are: the descriptive method had descried challenges that confront the human development in Jordan, and the analytical method, because plenty of matters related with these challenges need explanation and analysis to obtain means of limiting them, that is to reach results and then providing recommendations, and from part of dividing the study, we will tackle it in accordance with two demands, they are:

\section{Challenges of Human Development in Jordan}

The human development challenges include a group of axes, that cover the following fields: the economic field, the social field, the political field, and the environmental field. These fields are connected with each other an integrated connection and also interactive to form their outlets and returns from the necessary resources to satisfy the needs and develop the abilities that go on in turn in processes of production and in the different fields of the societal and individual life.

\subsection{The Economic Field and Human Development in Jordan}

This field forms a significant resource of the resources, upon which the human development depends. For this field concentrates on processes of economic growth and increase of national economy as a necessary condition, but it is not satisfactory alone to achieve the human development for existence of obstacles confront the Jordan human development, the most significant of them are:

a. Jordan hosting great numbers of Iraqi and Syrian refugees: the flow of Syrian refugees to Jordan was great. Eighty four percent of these Syrians live in the hosting communities instead of Refugees camps. Refugees exhausted the economic infrastructure and resources in Jordan, which were originally suffering from structural problems before the break-out of the refugees' crisis. The general feeling towards the Syrian refugees has an impact on the ability of the government on response in a fruitful form for the flow of refugees and Jordan lost trust in the support of the international granting parties, and decrease of financing. And without obtaining additional aids and everlasting response to the refugees crisis, Jordan will continue tightening the scope of protecting the Syrians. Thereupon, performing that will increase risks of non-settlement in Jordan and the region at the long run (Francisk, 2015: 7).

b. Retreat of agricultural, industrial, and trading production negatively affected the increase of unemployment averages, especially at the new generation and decrease of living level, the thing that led to addition of another challenge factor to the human resources in Jordan (Jordan Times News papers, issued on August 27 $7^{\text {th }}, 2017$ ).

c. Energy challenge: Jordan abundantly depends on sources of the foreign energy, and the high costs of importing petroleum (oil) led to raising loans and increasing the indebtedness. 
d. Rise of the public debt, especially the foreign and refuge to international loans to cover shortage in the general budget, and debt became forming a heavy burden on development more than being a replacement opportunity, this debt also formed a burden on the present and the coming generations in the shadow of non-availability of comprehensive and connected economic policies working on investment with high efficiency (Al-A'nani, 2013: 12).

e. Limitedness of the private sector role in the local economic activity, because of procedural obstacles that caused the absence of labors environment attracting investment; for the rate of its sharing in generating the local product did not overstep (\%18) in 2016, and it is one of the most important developmental challenges of the human an resources (Al-A'nani, 2013: 15).

f. Stop an cessation of financial aids that Jordan received from numerous Arab Oil States, determined to Jordan by the consecutive Arab Summit conferences, that is because of the World economic stagnation and lowness of money prices at the lowest of their levels (Qusaifi, 1995: 25-26).

g. Processes of economic -social transformations and programs of structural reform assisted to some negative effects, for they led to happening of slowness in the economic growth, because the processes of privatization and agreement of partnership with European Union and the World Trade Organization (WTO) forced the national industries to rearrange their conditions in the form that gets in harmony with demands and conditions of the new stage, and resulted from this all the entering of competitive new industries to the market, such as the medical and electric industries, marble, tissues, tobacco, and getting some of them out for inability on competition, the matter that led to slowness in the economic growth (Ministry of Planning, 2000: 24).

These obstacles had formed a challenge confronting the economic development reflected in a form of relevant in averages of the Jordan economic growth, the matter that reflected negatively on the income of the Jordanian individual, the thing that pushed the Jordanian governments to submit the reformation of transformations to raise the economic and social levels of the poor groups, that caught their tough track on two levels: level of the developing economic crisis since mid-eighties of the twentieth century till now, and level of negative results and the non-wished effects that resulted from the economic reformation raised by the consecutive governments to correct the private defects in the economy and the arbitrariness that accompanied its application on the state since a decade and a half, and left difficult effects for deep-rooted poor groups in Jordan, and the government and connected the economic reform project with one of its most important basic supports; that is the comprehensive development led by programs of the economic transformations, and drawing policies of the human development. For it is not reasonable to part the process, so Jordan calls for the liberal economy and liberation of markets in addition to enhancing specialty, and in the same time ignores the political democracy, and we perceive that laws aiming at merging the national economy in its worldly frame should be legislated by parliaments representing peoples and be applied by responsible governments (realities, Jordanian documents, second quarter, 2000: 222-229), the solution of such problems are not done except by building true partnership between both public and private sectors, in accordance with it the private sector becomes the motivator and the directive of it.

\subsection{The Social Field and the Human Development in Jordan}

This field covers all domains in relation with human development such as medicine, education, social-care, social development, family, social, housing, cohesiveness and social peace, and all what relates with welfare and making available all demands of individual and the group. And this domain plays on essential role in the economic field because of that fields that form the social field is considered an investment, besides being service formations. But it is not satisfactory alone to achieve the human development for existence of obstacles confront the Jordan human development, the most important of which are:

\subsubsection{Unemployment}

This is from the most important challenges that confront the means of human development, the matter that is negatively reflected on the human development; for this group works till fulfills the necessary needs for it from garments, drink, and food, and the average of unemployment for the year 2018 raised to $\% 19.2$ meanwhile the average of unemployment among bearers of the university certificate, they are the qualified group amounted to the rate \%25.9 in the year 2019 (Al-Ghad Newspaper, 2019).

\subsubsection{Defect Culture}

It means abstention of Jordanians from some labors, where there are plenty domains of works, if Jordanians practiced them the level of unemployment will be low from a part, and fill times of youths with serious and 
fruitful work, such as agriculture and guardianship and else, that is fearing from the sarcastic outlook of the community to them (Fanos, 2019) from another part.

\subsubsection{Customs and Traditions}

That make barriers between the oneself and the application of taken decisions by the legislative authorities in the state, where man seeks refuge at the incubator of tribe to raise from him the verdict issued on his own, and this returns us to the legislation of the forest and leads the state to be ruled by customs and tribal traditions, that in all is a challenge confronts the contemporary state (Abdel Majeed, 2019).

\subsubsection{Rarefaction of Social System}

This challenges became clear in our Jordanian community, and its causes are abundant of them entry of new element within the Jordan social tissue, as a result of circumstances that invaded the region at the last period, in addition to abundance of divorce cases, that led to many family problems and go far from verdicts of Islam with which abundant verdicts various solutions to the community problems, which is termed with the Arab Spring (Al-Fanik, 2012).

\subsubsection{Means and Favoritism}

Both phenomena of means and favoritism are considered from the most important phenomenon that leaves negative impacts on the native land and the citizen, and stand an obstacle in front of achieving justice and equality among citizens, so the street is divided into two parties; supporting: this is the benefitting group and opposing: this is the dissatisfied group, whose rights are oppressed (Al-A'rwani, 2018).

\subsubsection{Poverty and Lowness of Living Level}

The lowness of the individual income led to impacts cleared from through poverty and lowness of living level of families, the thing that led to enlarging the extent of social problems, from them pushing a group of children to labor, and this is a problem that lays its impacts on children, who practice labor at an early age stage on the expense of basic education and appropriate training on their abilities, so poverty and lowness of living level push children to escape to the labor- market till the income of these shares in fulfilling the needs of families, in forming that this age group is not trained to improve the required product (Ministry of labor, 2019).

If the obstacles of economic growth and their negative impacts that were prominent as one of the difficult challenges that confront the Jordan economy formed a heavy care on the Jordanian citizen in shadow of difficult economic, political, regional and international circumstances, it is threatening a part of his human security, so the social field that plays an integrated role with the economy field, to lighten from impacts of the economic problem that became a part of the life of the Jordanian citizen on consecutive periods since the emergence of the Jordanian state until today (Daraj, 2012: 139-184).

The greatest challenges separated by the economic labyrinth in its social field is how the Jordan government to employ all its energies in the domain of reformation and human development to get rid of the high averages of poverty and unemployment, Jordan really suffers from this everlasting labyrinth that affects the national abilities, and increases the citizen's suffering, who deserves to be saved for him a good life, and though governments raised the slogan of the comprehensive development in all domains and enhancing the role of funds of the social assistance and integration of their roles, and carrying out the social parcel (The Royal Command Letter, to Abdel Ra'oof Al-Rowabdeh's Government, 1999, the Electronic Site of King Abdullah $2^{\text {nd }}$ ).

\subsection{The Political Field and Human Development in Jordan}

This field covers issues like the political participation, multitude, freedom, respect of human rights, security and settlement, civil peace, sovereignty of law and transparency. This field demands activating the machinery and democratic associations, that allow individuals to share in formulating and carrying out decisions and policies practiced by the executive authority, and relate with their life, interests, future, and practicing their freedoms and their human rights, so the human development will not be complete without freedoms, and human rights work on liberating man from all restrictions that stand against obtaining his needs, and also grants him traits of ability of diversing and enlarging the basis of alternatives in his life (A'bbas, 2013).

Oneself's loss of ability to practice freedom in the process of choice may push him to a state of despondence and frustration and non-feeling with peace. Also frustration merging from absence of freedom, participation and disabling the democratic machineries many lead to states of disorder and anarchism, and perhaps lack of the civil peace, especially if accompanied by deterioration in both fields of economy and the community, but the most prominent political challenges that confront the human development in Jordan are: 


\subsubsection{Political Reformations}

They are represented in non-adoption of true political reformations to push the citizen towards participation in the political process, because of spread of the phenomenon of favoritism and rise of unemployment percent rate and absence of social justice and spread of the financial corruption phenomenon (Al-O'dwan, and Al-Hazaimeh, 2016). By that the human development becomes as the security valve, internal and external peace, because vanity of security and settlement are connected with factors of poverty, retardation, and social justice, and when people can develop their human skills by improving the conditions related with health, education and labor, that exert to work on enlarging alternatives in front of them in achieving appropriate level of good life, and a means to improve the life of humans and make opportunities of justice available in distributing the returns of development, either for the present or the coming generations, so the essential trait with which the process of everlasting development enjoys enables the generations from continuation in the process of development and harvesting its fruits (Mansour, 2009: 23-29).

\subsubsection{Lowness of Political Participation}

The political participation had formed a basic national necessity, because it is an indispensable demand from demands of achieving the national unity, that is considered a prop of achieving security and settlement, as two conditions accompanying the start of the process of the necessary development, and the new legislations allowed the political participation in Jordan for all conventional, political and dogmatic visions from which the Jordanian community consists (Al-Qatatsheh, 2001).

\subsubsection{Stumbling the Taking with Democratic Ruling}

Challenge is represented by guaranteeing free and fair elections and favoritism and respecting the constitutional affirmations and respect of thinking freedom. Jordan continued in stabilizing and drawing the milestones of the democratic transformations starting from the principle of enlarging the basis of freedoms and political participation, because they are the basis upon which the true democracy is built, and this freedom is obliged not to be employed at a form abuses to Jordan and above that with what abuses to our national unity (The Jordanian incidents and documents, the fourth quarter, 2000, 76-77).

a. The political elites that grow with the interests of the regime, and do not look to interests of the whole population and had possessed the resources of the state alone, and made the equation of matrimony of the authority with the capital easy, and did not merge between the indicator of the living roof top of citizens and incomes they obtain, and did not concern about covering the country with the developmental equal with anything else, for the sake of conserving their particular interests (Al-A'dwan\& Al-Hazaimeh, 2016: 685).

Perception of the Jordan decision-maker was that the risks confronted by Jordan in the contemporary era will not be by a foreign occupation of the country or an armed aggression from the regional outside, but it will be represented by evacuating the political life from its content, weakening associations of the civil community, by deterioration of the people living level at its lowest limits, and increase of poverty averages and unemployment, and increase of social conflict risks as a result of economic conditions, and it pushes the people to extremism and go far from the principles of dialogue and middle distance, because of democracy absence (Al-Masri, 2000).

b. Regional political conditions: formed political challenge in confronting the human development, and in shadow of hastening of the regional incidents in Iraq and Palestine, and the local circumstances; so the objective of Jordanian governments was at these two issues, the thing that was negatively reflected on the subject of political development and democratic transformation.

And the incidents in Palestine and war in Iraq imposed themselves on Jordan; for the government started tending to control the political and crowd powers to form seemed to many people that it forms a retreat from the programs of political development and democratic transformations, but from a second part, the absence of the democratic political life in Jordan for long decades had the greatest effect in the issue of democracy. "The factional life in the present time is a stumbled experience, and this stumbling is the blame in it, does not happen on the shoulder of the executive authority alone, but on factions themselves that are living in challenge imposed on them to reach mutual divisions, and to submit true national programs that make them factions with credibility, polarize citizen, allow them the effective participation in the public life, and the best investment of their energies in all domains, and this demands the factions to lay for themselves political, economic, social, national and real programs" (Ministry of Planning and International Cooperation, (2002) "Document of Jordan First"). 


\subsection{The Environmental Field and the Human Development in Jordan}

The environmental field is one of the important domains..it is a basic pillar of the human development, and the environment represents a proper resource from the affective resources in this development, and the policies led by the modern state gives the environmental side a special significance in the raised developmental projects, and observes the consuming patterns conserving rights of the coming generations and achieving the everlasting development, the challenges of this field are represented by the following:

a. Ministry the natural resources and extravagance in them leads to wasting and destroying them, such as social sweeping away and wasting its fertility, pollution of air and sources of water, rivers and oceans because of the action of lefts of industry and by extravagances in using energy, and from processes of getting rid of harming nuclear and non-nuclear garbage, and the literature and animal remains, in addition to non-activating the legislations concerning environment protection sources of energy and their resources, all that led to the environmental destruction (Nasar, 1997: 5).

b. Desertification: it is represents in decreasing the area of agricultural lands and fewness of the agricultural national production, because of the fewness of the water resources, that led to increase the patch of desertification, made from Jordan an environment excluding the local manpower, and led to increasing the immigration of the population into cities searching for labor, and this in turn led to disclosing large areas without exploitation, the thing that made the environment form a challenge of the human development challenges in Jordan. The limiting of qualification and maintenance of water-nets in municipalities at their different levels in cities and villages, drinking-water and its inability to fulfill the necessary needs for the population, especially in summer days, in addition to a qualified plan to face the air-circumstances, especially in winter, that led to sinking Jordanian cities and victims passing away by sinking, because of air-conditions in which the infrastructure became in case of inability to absorb happenings of such incidents.

c. Destruction of environment: In shadow of globalization and the flow of investing capitalism it became possible to transfer industries to their rough sources and buying markets in different zones of the world, so globalization facilitates the processes of industrial investment. These industries will spread in all directions of the whole earth and increase the average of production by action of the increase of consumption average, and these policies, in addition to being destroying the environment, they are also working to waste the natural resources hastily, and representing a danger on the everlasting development that its axis is man at present and the future (Incidents and Jordan documents, fourth quarter, 1999, P. 156). The thing that caused deterioration to some elements of environmental systems.

d. Challenge of Water-Source Rarity: Jordan is considered one of the ten poorest countries in the world from part of water-sources, and the crisis had aggravated by the flow of more than one million persons of the Syrian Refugees since the civil war in their country broke out (Muhafzah et al., 2016: 254). So the fundamental solution to the challenge of water-decrease can be achieved through:

I. Challenge of energy, for the solution of the water problem requires saving energy with acceptable prices to be used in processes of transportation, decoration, returning, storage and distribution.

II. Doing on effective procedures to direct consuming water, especially in the agricultural sector.

III. Reforming the worn-out nets of water,

IV. Cessation of aggressions on nets of water and the inside water.

V. Serious seeking to review the signed agreements with each of Israel and Syria to restore the share of Jordan from water share in the River Jordan.

Jordan had been exposed by action of modernization and urbanization to a group of change and transformations that imposed great challenges on its natural resources at a degree conserving these resources became a general national concern at both levels: the formal and the national, so by increasing the human economic and industrial activity increased the negative effects resulting from this activity, and hasting enlargement in the communication sector, the architectural enlargement of cities, the civilized and country side assemblies, the growing increase of population, increase of demand for the agricultural and nutritious products, and the increasing development in sectors of energy and mining resulted from them negative results warning with the increasing danger about the safety and future of the environment and its resources in Jordan.

And in the year 1995 the government did accomplish the labor- plans to protect the environment, followed that in the same year the determination of law No. (129) concerned with protection of the environment in accordance 
with which the Public Association for Protecting the Environment was established by the Council of the Nation (Council of Al-Uamma), and in January, 2003 The "Royal Will" had been issued to originate a ministry particular for the environment (Formal Newspaper No. 45510, dated 16/1/2003).

\section{Challenges of the Human Development in Jordan and Means of Limiting Them}

The challenge of the human development in Jordan are abundant and numerous, so the decision -maker and those who are responsible for the human development have to employ the means that limit them, for the sake of deducing a human development with which man of these countries can promote with himself in particular and his country in general.

To achieve "The Comprehensive Development ", for it is a necessary basis for prosperity and welfare, and its achievement requires integration in the political, economic and social domains and there have to take a methodology distinguished with modernism and initiative, and this vision leans on rules and new machineries (The Royal Speech of the Throne in Opening the First Round of the $14^{\text {th }}$ Upper House "the Council of the Nation", $1^{\text {st }}$. December, 2003).

Rules of limiting the human developments challenges are represented in the following:

1. Dedication of integration and cooperation community on a basis of justice, equality, equivalence of opportunities, respect of human rights, depending the principle of fairness and transparency and appeal to sovereignty of the law on all.

2. Share all categories of the community in the process of development, especially youths and the woman.

3. Generalization of democracy culture to make prominent of the conformity of the Jordanians aspirations.

4. The comprehensive development obliges developing the juristic body fortified by independence.

5. Rooted changing of decision-making machineries in accordance with plans and strategic programs.

To attain a comprehensive development with its economic and social dimensions starting towards the true alternation, that demands from the government to start from evident bases and practical machineries, and laying a national strategy, with medium extent concerns with training the human powers, that are the basis of development and its activator, for the sake of fulfilling the changing needs of labor-market and the economic activity. The Jordan human is always the objective of development and its basis, and from here was the desire for the significance of investment by the human capital through training, education, and qualification (Letter of Reply) on the Royal Letter to (Faisal Al-Fayez's Government, October $25^{\text {th }}$., 2003). That is for the sake of embodying the principles of justice and equivalence of opportunities Taxes of limiting the human developments challenges adopted by Jordan in its present plans are numerous significant domains (Ministry of Planning, 2003):

a. Achieving the economic growth leading to improving the life of citizens, making labor-opportunities available and limiting both problems of poverty and unemployment.

b. Achieving the social justice among groups and classes of the community.

c. Practice of rational government and enlargement of participation in plans, programs and policies through the different associations.

d. Protection of environment and renewing it, and the correct management of the human resources. 2006):

But the machineries demanded by development of human resources, they are (Abu Zant \& Ghneim,

a. Making continued education available through all concerned associations.

b. Laying the necessary practical machineries to activated partnership among the national sectors.

c. Improving the level of attaining knowledge and information through integrated structure in the domain of information technology.

d. Enhancing the abilities in the domain of research and development.

e. Adopting a national program for the political, economic and administrative reformation.

The Jordanian strategy in the domain of everlasting human development starts from a group of general collective objectives, they are: (Ministry of Planning, 2000: 202):

Firstly: improving the type of life to all citizens through employing appropriate policies, housing and developing programs aiming at decreasing poverty achieving the economic growth and development of the human resources, and respect of human rights including the woman rights and child. 
Secondly: bridging the gap among regions in the different social and economic domains.

Thirdly: limiting patterns of consumption and non-everlasting production and also limiting the negative impacts of the demographic factors on the environment, by fulfilling the present generations needs from different resources without hurting the interest of the coming generations.

And from the point $\mathrm{f}$ view of the Jordanian decision maker, it has to be drawn integrated programs for the reformation in the Jordanian State, because "our vision for Jordan empowerment to make firm the pillars of its new experience, and the elements of Jordan power in the future are keeping its distinction as a model in the political and economic openness, security, settlement, democracy and adopting the concept of comprehensive development with its different dimensions. The world around us changes, and all are preoccupied with processes of development, to escort challenges of the age with new tools and styles and wear too dealing with reality by a new language, till we can be able to proceed forward with confident steps to achieve the appropriate future to us through guaranteeing sharing of the different efficacies and the popular bases in the process of development and make happen the change. We are confident that our reforming programs will achieve their hoped results, and we are instating on going forward in our seeking toward building the modern Jordan, performed on multitudinous, democracy, moderateness, and decentralization. And this demands enlarging the basis of popular partnership in the track of reformation and development that comes in the context of a constant comprehensive process (The King's meeting with the French News Agency, Jan. 27 ${ }^{\text {th }} .2005$, the electronic Site of King Abdullah II).

The document issued by representatives of both sectors, public and private on abundant recommendations and they are (recommendations of the Dead Sea Conference, November $26^{\text {th }}, 1999$, King Abdullah $2^{\text {nd }}$ s electronic Site):

a. Starting from method of liberation and economic and economic modernization for Jordan.

b. Performing necessary financial reformations.

c. Commencing judicial reformations.

d. Reforming the general administrative body.

e. Performing a parcel of legislative amendments in different domains.

And to confront the challenges imposed by the crisis of energy and its direct impacts on the economic and social development, a comprehensive national strategy had been developed for the sector of energy in the year 2004, had been modernized in the year 2007 to cover the period (2007-2020), the most prominent of objectives were typifying sources of energy (Muhafezah, 2016: 251-253).

a. Enlargement in projects of renewed energy, to generate the electric energy from the solar energy and from energy of winds.

b. Insertion of oil-rock as a replacement of generating the electric energy.

c. Insertion of nuclear energy as a replacement of generation.

d. Achieving the project of both seas canal: it is an environmental water through establishing a canal connects between the Red Sea and the Dead Sea, for rescuing the Dead Sea from the decrease of water level, and generate electricity, and participation individual tourism projects, and economic projects and solving the problem of unemployment and poverty (Muhafezah, 2016: 268).

And in the domain of developing the human resources, the Jordanian governments had submitted a group of procedures included by the national program, concentrated on the necessity of developing teaching curriculums with what achieves a strategy takes into consideration all elements the educational and teaching process, and applying national programs for the vocational training, and establishing institutes for the specialized training identical to those existing in the developed states.

\section{Conclusion}

At studying the challenges that confront the human element in Jordan, performed on a hypothesis meaning: that there is a correlative relationship clears the challenges and the human development. The study deduced at the end the correctness of the hypothesis, and also deduced conclusions obliged numerous recommendations, they are:

\subsection{Results of Study}

a. Jordan is full of challenges about to cover everything, and the community of Jordan is not excepted of that, and from those challenges: the political, economic and social challenges. 
b. Jordan views that the best model for reformation is that springing from the inside. King Abdullah II did lay an integrated agenda aims at treating the primary issues that concern with the Jordanian citizen represented in enhancing the political development and freedoms of individuals, role of the woman and youths and working on improving the proficiency of judicature, restructuring education, and achieving a positive economic growth, firm through which improving the individual's living circumstances can be done at a form guarantees building a community more developed and advanced open and tolerant.

c. King Abdullah, the Second's aim was to assert the necessity of deepening the bases of democracy and enlarging the political participation, and developing the political, economic, social and educational domains and care about youths, and to rise with the role of the woman, beside developing associations of the social work, promotion of education, and accomplishing a mutual Arab market.

d. King Abdullah's perception of problems from which Jordan suffers in the domain of development, starts from the necessity of solving the economic labyrinth, that it will never be solved without building a true partnership between both public and private sectors, the private sector in accordance with it is the propeller and the main instructor of activities.

e. Making the human development appear in the Jordanian political speech by King Abdullah, the Second, who always concentrates on achieving the economic development, not only for pure economic objectives, but to other political, social and environmental objectives as well at strong link with settlement and security objectives.

f. Plans of human development in Jordan aim at saving the political, social, economic, civil rights and freedom of expression, the thing that enhances the type of life and continuation of good opportunities for consecutive generations, and allowing opportunities of labor in front of all to be able to participate in the process of development.

g. Jordan had stepped large steps on the road of human development, inspite of challenges it passed by, but plans adopted by Jordan on the level of the programs of economic and social transformations asserted on numerous axes that concentration of the concept of the everlasting human development.

\subsection{Recommendations}

a. Continuation in enhancing the democratic transformations, the political multitude, and activation of the political factions role.

b. Carrying out the economic programs to achieve the human development.

c. Doing administrative, judicial, and legislative reformations to build bases of the modern state, that is the state of law and associations, and community of justice and equality.

d. Practical and scientific assertion on the principle of truthful partnership between the private sector and state in the process of development and investment. And it is also obliged to encourage cooperation between both sectors: the public and private by removing the legal obstacles and the unnecessary administrative procedures.

e. Laying a comprehensive strategy for the economic, social and political development in Jordan.

f. Necessity of enhancing partnership between both public and private sectors on both levels; the local and the external, that is to save the building ideas and offering the necessary solutions for the challenges that confront Jordan.

\section{References}

Abdel Majeed, Waheeb. (2016). Manis Prisoner of Assembled Customs, Al-Jazeera Codes, November $11^{\text {th }}$., 2016.

Abbas, Khaled Saleh. (2013). Concept of Development and its Connection with Human Rights Between Intellectual Riches and Challenges, Journal of Babel University, Humanities, 21(2), 617-631.

Al-Ahmad, Suheil, (2012). Human Resources Development from an Islamic Perspective. Journal of Al-Aqsa University (Series of Humanities), 16(1), 145-169.

Al-A'nani, Jawad. (2013). Burdens of External Debt, Paper Work Submitted to the Conference of the Arab Homeland Economies, The Dead Sea, Jordan.

Al-Fanik, Fahd. (2012). What is After the Arab Spring, The Jordan Times, 22/7/2012. 
Al-U'rwani, Abdel Aziz. (2018). Intermediary and Favoritism Where for?, The Jordan Times, Issued on April $17^{\text {th }}$., 2018.

Al-U'dwan, Abdel Haleem, \& Al-Hazaimeh, Mohammad A'wad. (2016). The Political Reformation and the Arab Political Systems in the Perception of Political Sciences Instructors at the Jordanian Universities: A Surveying Study. Volume of Studies Humanities, University of Jordan, 43(2), 677-704.

Abu Zant, Majidah, \& GhneimO'thman. (2006). The Everlasting Development: A Theoretical Study in the Concept and the Content, Al-Manarah, Al-Al-Bait University, Mafraq, Jordan, 12(1), 150-172.

Al-Sayyabi, Taleb. (2017). The Human Development and its Impact in the Omani Community to Achieve the Everlasting Development, Doctorate Dissertation, Islamic Studies Academy, Malaya University, Kuala Lumpur.

Al-Nashat, Saleh. (2014). Social Challenges and Their Impact on the Human Resources Development: A Sociological Prologue, The National Center for Developing the Human Resources, Amman.

Al-Burai', Mohammad Abdullah, \& Al-Tweijri, Mohammad Ibrahim. (1993). Dictionary of Administrative Terms: English- Arabic, Al-I’beikan Bookshop, Riyadh.

Al-Jawhari, Abdel Hadi, et, al. (1986). Studies on Social Development, Nahdat Al-Sharq Bookshop (Renaissance of Orient Bookshop), Cairo.

Al-Sadeq, Sadeq. (2012). Definition and the Concept of Human Resources, The Arab Forum for Management of the Human Resources, 28/1/2012. http://hrdiscussion.com/hr42360.html

Al-Qatatsheh, Mohammad Hamad. (2001). Development of the Political Life in Jordan in King Hussein Region, Sa'ad Bookshop, Amman

Al-Masri, Taher. (2000). Reality of the Political Life in Jordan and Aspirations of the Future, Shown on Cultural Forum, Amman, Jordan 27/3/2000.

Al-Muhafezah, Ali et, al. (2016). National Education $2^{\text {nd }}$ ed., Dar Jareer for Publication and Distribution, Amman.

Mansour, A'zmi. (2009). Contemporary Issues, Treasures of Scientific Knowledge for Publication and Distribution, Amman.

Darraj, Faisal. (2012). The Arab World, its Labyrinths, and the Hoped Reformation, Ministry of Culture, Amman.

Fathi, Anees. (2005). Emirates Where for Orientalizing Challenges and Risks all Along 25 Years, Emirates Center for Media Studies, Abu Dhabi.

Fanoos, Kareem I'mad. (2019). Culture of Disagree in Jordan, The Jordan Times, issued on May $19^{\text {th }}$., 2019.

Francis, Alexandra. (2015). Jordan's Refugee Crisis, Carnegie Endowment for International Peace, September 21-2015.

Jordan Ministry of Planning and International Cooperation. (2000). Plan of Economic and Social Development for the Years 1999-2003, Amman.

Jordan Ministry of Planning and International Cooperation. (2003). Plan of Economic and Social Development for the Years 2004-2006, Amman.

Hasan, Abdel Baset Ahmad. (1998). Social Development. Wahbeh Library, Cairo.

Qusaifi, George. (1995). The Human Development, A Critical Review of the Concept and the Content, Center for the Arab Unity, Beirut.

Mohammad, SamirahKamil. (1984). Social Development: Basic Concepts- Real Visions, Modern University Office, Alexandria.

Ministry of Labor. (2019). Poverty and Unemployment and Lowness of Living Level in Jordan, Published Report, Jordan, June 11.

Ministry of Planning and International Cooperation. (2002). Document of Jordan First, Amman, Jordan.

Nassar, Ali. (1997). The Human Development Towards An Attempt for Formulation of An Arab Point of View in the Concept and Analogy, Series of Human Development Studies, (4), United Nations, New York. 
Radwan, Mahmoud Abdel Fattah. (2013). The Basic Strategies in Managing the Human Resources, The Arab Group for Training and Distribution, Cairo.

The Jordanian Al-Ghad Newspaper. (2019). Rise of Unemployment Average, Issued on September $1^{\text {st }}, 2019$.

Suleiman, Huda Tawfiq. (1436H.). The Social Challenges in the Arab World in the millennium (The New Decades), A Paper Work Submitted to the Conference of the Social Protection and Development $1437 \mathrm{H}$. Safar 2-4, Nayef Arab University for Security Sciences, Riyadh.

Sawsan, Mureibi'. (2013). Social Development in Algeria; Reality and Horizons - Master Degree Dissertation, Mintouri University-02-, Faculty of Economic Sciences and Sciences of Algerian Propulsion.

Zahu, Saber Mohammad. (2015). The Human Development in Iraq in Shadow of Knowledge Economy, Journal of Faculty of Administration and Economics, University of Human Development, Al-Suleimaniyah, Iraq, (2), 23-202.

\section{Copyrights}

Copyright for this article is retained by the author(s), with first publication rights granted to the journal.

This is an open-access article distributed under the terms and conditions of the Creative Commons Attribution license (http://creativecommons.org/licenses/by/3.0/). 